\title{
Pediatric Nephrotic Syndrome; Clinical Characteristics and Nutritional Status
}

\author{
Ali Ateia Elmabsout ${ }^{1}$, Hajir Omar Tawfeeq ${ }^{2}$ and Jebril Elabidi ${ }^{{ }^{3}}$ \\ ${ }^{1}$ Department of nutrition, Faculty of Public health, University of Benghazi. Benghazi. Libya \\ ${ }^{2}$ Pediatric hospital, Benghazi. Benghazi. Libya \\ ${ }^{3}$ Faculty of Medicine, University of Benghazi. Benghazi. Libya
}

Received: 15 February 2020/ Accepted: 15 July 2020

Doi: https://doi.org/10.54172/mjsc.v35i1.226

\begin{abstract}
Nephrotic syndrome (NS), is the most common chronic renal disorder in children, with multifactorial risk factors and complex etiology. Therefore, the aim of the present study was to determine the age and gender distribution and also determine the clinical characteristics and nutritional status of pediatric nephrotic syndrome. A total of 75 patients with nephrotic syndrome series were selected through semi-constructed questionnaires. The age of our subjects ranged between 118 years. Body weight and height were extracted from patient files or self-reported to calculate BMI percentile. Laboratory tests such as blood glucose, lipid profile vitamin D, and $\mathrm{HbA} 1 \mathrm{C}$ were included. All samples were analyzed through either mean \pm SEM or Chi-square for determining significant differences. The present study showed that 75 patients were diagnosed as nephrotic syndrome. The average age of patients was 9 years old and the age which showed significance was 6-10 years $(\mathrm{p}=0.04)$. In comparison to females, males were highly significant $(\mathrm{p}=0.000)$. Blood biochemistry showed low levels of total protein, albumin, hemoglobin, HCT, MCV, WBC, (gran \%), calcium and sodium, and high levels for lymphocyte (mid \%), urea, creatinine, ESR, potassium, hematuria, serum cholesterol, TG and VLDL. All patients were diagnosed as idiopathic nephrotic syndrome. Low birth weight showed significant increase in nephrotic diseases $(p<0.05)$. Nutritional indices showed high body weight status with more junk and nutritious foods consumed among nephrotic patients. The present study revealed that nephrotic syndrome significantly increased in males $(\mathrm{p}<0.05)$ and male to female ratio 2.6:1. It also showed that the age groups between 6-10 years are more prone to suffer from a nephrotic disease $(\mathrm{p}<0.05)$. A history of low birth weight in infants or child family ranking were shown to be risk factors contributing to nephrotic disease $(p=0.000)$.
\end{abstract}

Keywords: Nephrotic Syndrome; Diet; Pediatrics; Nutrition.

\section{INTRODUCTION}

Nephrotic syndrome (NS) is a set of signs or symptoms that may point to kidney problems. Both adults and children can have nephrotic syndrome. The causes of and treatments for nephrotic syndrome in children are sometimes different from the causes and treatments in adults. Childhood nephrotic syndrome can occur at any age but is most common between the ages of 1 year 6 months and 5 years. It seems to affect boys more than girls (Srivastava et al., 1975). Nephrotic syndrome is a serious chronic disease in children, characterized by minimal change disease in the majority. Research on pathogenesis has emphasized the importance of T lymphocyte dysregulation and vascular permeability factors that alter podocyte function and permselectivity. Patients with nephrotic syndrome are at risk of life-threatening infections and thromboembolic episodes (Avner et al., 2016). 
The estimated annual incidence of nephrotic syndrome in healthy children is 2 to 7 new cases per 100,000 children younger than 18 years of age, making it a relatively common major disease in pediatrics. Approximately $50 \%$ of affected children are between the ages of 1 year 6 months and 5 years; $75 \%$ are younger than 10 years of age (Neuhaus et al., 1995). Nephrotic syndrome is a common chronic disorder characterized by alterations of permselectivity at the glomerular capillary wall, resulting in its inability to restrict the urinary loss of protein. Nephrotic range proteinuria is defined as proteinuria, exceeding $1,000 \mathrm{mg} / \mathrm{m} 2$ per day or random urine protein-to-creatinine exceeding $2 \mathrm{mg} / \mathrm{mg}$. The proteinuria in childhood nephrotic syndrome is relatively selective, primarily constituted by albumin. Studies have reported prevalence from 12 to 16 per $100,000.1$. It occurs more in children of South Asia where the condition is primary (idiopathic) in $95 \%$ of cases. An underlying disorder that may be identified includes systemic lupus erythematosus, Henoch Schonlein purpura, amyloidosis, HIV infection, parvovirus B, and Hepatitis B and $\mathrm{C}$ viruses. Nephrotic syndrome has been generally stable over the past 3 decades, the histological pattern is changing (Bagga et al., 1996). There is an increased risk of proteinenergy malnutrition in children with nephrotic syndrome (Ladapo et al., 2014). Children with nephrotic syndrome are prone to both macro and micronutrient deficiency and are at risk of poor growth, muscle mass depletion, and cognitive impairment (Grimbert et al., 2003).

Nutritional deficiency in nephrotic syndrome occurs from the disease process, poor dietary intake, and steroid therapy. It is a major contributor to morbidity and mortality in affected children. Nutritional assessment and maintenance of adequate nutrition are important in children with nephrotic syndrome. Nutrition affects growth, neurocognitive and pubertal development (Gordillo \& Spitzer, 2009). The importance of assessing the nutritional status of children with renal diseases by pediatric nephrologists was reported by MontalvoVilvar and co-researchers (Lenenno et al., 2010). Nutrition is a modifiable risk factor for mortality and should be routinely monitored in children with renal dysfunction. In the previously mentioned study, about 109 $(50.9 \%)$ of the subjects had nephrotic syndrome. Subjects between 2 and 9 years that had malnutrition and were stunted, mostly had nephrotic syndrome.

The recommended measurements for nutritional assessment in children with renal diseases include a review of dietary intake, assessment of serum albumin, height or length (and SD score), estimated dry weight, weight/height index, skinfold thickness, and mid-upper arm circumference (Byham-Gray et al., 2014). There is scarce information about the clinical, biochemical and nutritional status of pediatrics nephrotic syndrome patients locally available. Therefore, the aim of the present study is to determine age and gender differences in nephrotic syndrome and also to determine clinical characteristic which includes risk factors and causes of nephrotic syndrome and the assessment of the nutritional status of patients by anthropometric indices, patterns of food intake, and blood biochemistry.

\section{MATERIAL AND METHODS}

A case series study was carried out from June 2017 to October 2017 on children and adolescences attending Benghazi Children's Hospital (BCH) in Benghazi, the secondlargest city in Libya. The samples consisted of 75 subjects (54 and 21 male and female respectively). Subject ages ranged from 1-18 years old, all of which were diagnosed with nephrotic syndrome from the department of nephrology. After obtaining written consent, subjects were requested to fill out a questionnaire with the involvement of their parents, especially for those younger than 15 years old, and proceed to a private area to have 
their height and weight measured. For a complete nutritional assessment, the questionnaire include questions for signs and symptoms, patterns of food intake, and biochemical investigations. Clinical characteristics and biochemical investigations were also obtained from patient registries. Clinical characteristics of nephrotic syndrome include signs, symptoms, and complications besides risk factors and causes of disease, during which the nutrition status was assessed by anthropometric measurement, biochemical investigation, and the food intake of patients, which all have been investigated in the selfconstructed questionnaire (Gordillo \& Spitzer, 2009).

Statistical analysis: The data from the questionnaires was entered using Excel. The data set was exported to SPSS v.18 and Epi-info for complete analysis. Statistical analysis was carried out for the complete sample, as well as for four different groups which were created according to measured BMI: underweight, normal, overweight, and obesity. For those younger than 18 years, BMI percentile was used. Mean values and standard deviation for all continuous variables: weight, height, BMI, and other variables for all groups were obtained. Frequencies for each categorical variable were also calculated for each group. To determine the differences regarding each categorical variable, a Chi-square test was performed.

\section{RESULTS}

Data collected on 75 patients from Benghazi children's hospital shows that the age of patients ranged from 1-18 years old, and the mean $\pm \mathrm{SD}$ of the age was $9 \pm 2$ years old. Nephrotic syndrome reaches a peak at the age group 10 years old and declines with age progression between 16-18 years old to reach from $14 \%$ to $2 \%$, and more predominant in age groups 6-10 years $(p=0.04)$ (Table 1A \& 1B). Through gender distribution, there was a significant increase in nephrotic syndrome in males by 2.6 times $(\mathrm{p}=0.000)$.
Table (1): age categories of the patients:

\begin{tabular}{llll}
\hline \hline Age categories & $\mathrm{N}$ & percentages $\%$ & $* \mathrm{P}$ values \\
\hline$\leq 5 \mathrm{yr}$. & 18 & $24.0 \%$ & \\
$6-10 \mathrm{yr}$. & 37 & $49.33 \%$ & 0.04 \\
$11-18 \mathrm{yr}$. & 20 & $26.66 \%$ & \\
Total & 75 & $100.0 \%$ & \\
\hline \hline
\end{tabular}

*Chi-square test was done and values of $\alpha<0.05$ were considered significant.

\section{Biochemical investigation of the patients:} In nephrotic syndrome patients, the blood biochemical test showed abnormally low levels of laboratory values for total protein, albumin, hemoglobin, HCT, MCV, WBC, (gran\%), calcium and sodium, and high levels for lymphocyte $(\operatorname{mid} \%)$, urea, creatinine, ESR, potassium, hematuria, serum cholesterol, TG, and VLDL (Table2A-B).

Table (2A): laboratory investigation finding of the patients

\begin{tabular}{ccc}
\hline $\begin{array}{c}\text { Laboratory } \\
\text { test }\end{array}$ & Mean \pm SEM & $*$ Reference values \\
\hline $\begin{array}{c}\text { blood total } \\
\text { protein }\end{array}$ & $5.2 \pm 0.2$ & $6.0-8.0 \mathrm{~g} / \mathrm{dl}$ \\
Albumin & $3.0 \pm 0.2$ & $3.5-5.0 \mathrm{~g} / \mathrm{dL}$ \\
Hemoglobin & $11.4 \pm 0.5$ & $12.0-16.0 \mathrm{~g} / \mathrm{dl}$ \\
$\mathrm{HCT}$ & $29.4 \pm 2.1$ & $35-45 \%$ \\
$\mathrm{MCV}$ & $50.4 \pm 7.4$ & $80-100 \mathrm{fl}$ \\
$\mathrm{MCH}$ & $27.9 \pm 2$ & $26-34 \mathrm{pg}$ \\
$\mathrm{MCHC}$ & $34.5 \pm 1.7$ & $33-37 \%$ \\
WBC & $10.2 \pm 0.6$ & $4.5-9.50 \times 103 / \mu 1$ \\
Lymph $\%$ & $28.9 \% \pm 2.9$ & $23-33 \%$ \\
mid $\%$ & $9.1 \% \pm 4.5 \%$ & $3.7-8 \%$ \\
gran $\%$ & $25.2 \% \pm 7.2 \%$ & $55 \%$ and $65 \%$. \\
\hline *Based on local laboratory values. &
\end{tabular}

Table (2B): Lipid profile finding of the patients:

\begin{tabular}{lll}
\hline \hline $\begin{array}{l}\text { Lipid pro- } \\
\text { file }\end{array}$ & Mean \pm SEM & *Reference values \\
\hline LDL & $94 \pm 22$ & $<100 \mathrm{mg} / \mathrm{dl}$ \\
HDL & $48 \pm 10$ & $>45 \mathrm{mg} / \mathrm{dl}$ \\
S. Choles- & $272 \pm 23$ & $<170 \mathrm{mg} / \mathrm{dl}$ \\
terol & & $75-99 \mathrm{mg} / \mathrm{dl}$ \\
S.TG & $254 \pm 48$ & $<30 \mathrm{mg} / \mathrm{dl}$ \\
VLDL & $51 \pm 2$. &
\end{tabular}


Some indicators and cause for nephrotic syndrome: In table (3), we attempt to look at an indicator of nephrotic syndrome in children and adolescences. We found a significant increase of protein in urea $(p=0.000)$, and $48 \%$ of cases reported manifestation of parasites in the urinalysis samples.

Table (3): indicator and possible cause of nephrotic syndrome

\begin{tabular}{|c|c|c|c|c|}
\hline \multicolumn{2}{|l|}{$\overline{\text { Factors }}$} & $\overline{\mathrm{N}}$ & $\begin{array}{l}\text { Percentage } \\
\%\end{array}$ & *P values \\
\hline \multirow[t]{2}{*}{$\begin{array}{l}\text { protein in } \\
\text { urine }\end{array}$} & inYes N & $\begin{array}{l}71 \\
4\end{array}$ & $\begin{array}{l}94.6 \% \\
5.4 \%\end{array}$ & 0.000 \\
\hline & Total & 75 & $100.0 \%$ & \\
\hline \multirow{3}{*}{$\begin{array}{l}\text { parasite } \\
\text { infestation }\end{array}$} & Yes & 36 & $48.0 \%$ & \\
\hline & No & 39 & $52.0 \%$ & \\
\hline & Total & 75 & $100.0 \%$ & \\
\hline
\end{tabular}

$\overline{\text { *Chi-square test was done and at } \alpha<0.05 \text { considered signifi- }}$ cant.

Investigation of risk factors of nephrotic syndrome in the patients: The ranking of a child in the family could be part of risk factors by which the most common child who got nephrotic syndrome was ranking second with low birth weight have high significance for nephrotic syndrome $(p=0.000)$. Neither Family history nor consanguinity play a further role in developing nephrotic diseases. In regards to the labor situation, around $46.6 \%$ showed delivery by cesarean section.

Clinical diagnosis and complications in patients with nephrotic syndrome: About tal nephrotic syndrome $(p=0.000)$, and nephrotic syndrome has been associated with some chronic disease, including mostly respiratory diseases, HTN, and diabetes $26.6 \%$, 17.4 and $9.4 \%$ respectively. The most complications were reported by patients were Proteinuria and edema $(p=0.02)$.

Types of treatment regimen received by patients: The majority of patients received corticosteroids medication (92\%), while other in the family. We also found that those born $85.3 \%$ of patients were diagnosed as congeni-

medications were used but less frequently. Those medications include (diuretics, antihypertensive agents, calcineurin inhibitors, and intravenous (IV) albumin).

Investigation if patients instructed to follow special diets: As shown in table (4), there were a significant number of patients who used salt-restricted diets and high protein diets $(\mathrm{p}<0.05)$.

Table (4): Patients following a specific diet:

\begin{tabular}{|c|c|c|c|c|}
\hline & & $\mathrm{N}$ & Percentages $\%$ & $* \mathrm{P}$ values \\
\hline $\begin{array}{l}\text { Salt re- } \\
\text { stricts diet }\end{array}$ & Yes & 50 & $65.0 \%$ & 0.000 \\
\hline \multirow{4}{*}{$\begin{array}{l}\text { high pro- } \\
\text { tein diet }\end{array}$} & $\begin{array}{l}\text { No } \\
\text { Total }\end{array}$ & $\begin{array}{l}25 \\
75\end{array}$ & $\begin{array}{l}35.0 \% \\
100.0 \%\end{array}$ & \\
\hline & Yes & 48 & $46.0 \%$ & 0.01 \\
\hline & No & 27 & $34.0 \%$ & \\
\hline & Total & 75 & $100.0 \%$ & \\
\hline
\end{tabular}

Anthropometric indices measurement for the patients: Anthropometric measurements carried out for the patients were body weight, height for (BMI percentile), and mid-arm circumferences for (degree of protein-energy malnutrition PEM). As shown in table (5), increased BMI was found by which obesity $(p=0.000$ vs $66.7 \%)$ but no degree of PEM were identified in patients.

Table (5): Anthropometric indices of patients

\begin{tabular}{lllll}
\hline \hline Physical measurements & $\mathrm{N}$ & $\begin{array}{l}\text { Percentages*P values } \\
\%\end{array}$ \\
\hline $\begin{array}{l}\text { Percentile } \\
\text { (BMI) }\end{array}$ & Normal & 10 & $13.3 \%$ & \\
& Overweight & 15 & $20.0 \%$ & \\
& Obese & 50 & $66.7 \%$ & 0.000 \\
& Total & 75 & $100.0 \%$ & \\
MAC and & Normal & 65 & $86.7 \%$ & \\
degree of & & & & \\
PEM & & 10 & $13.3 \%$ & \\
& Moderate & 75 & $100.0 \%$ & \\
\hline *Chi-square test was done and at $\alpha<0.05$ was considered signifi-
\end{tabular}
cant. 
Study of food intolerance and instructed patients by clinicians: Food intolerances were not common, but some cases were reported to have lactose intolerance and celiac disease (Table 6). 100\% of patients showed regular physician follow-ups, but this percentage showed a sharp decline for followups with a dietitian by which the reported No was $(90.7 \%)$.

Table (6): food intolerance and regular follow-up of health provider by patients

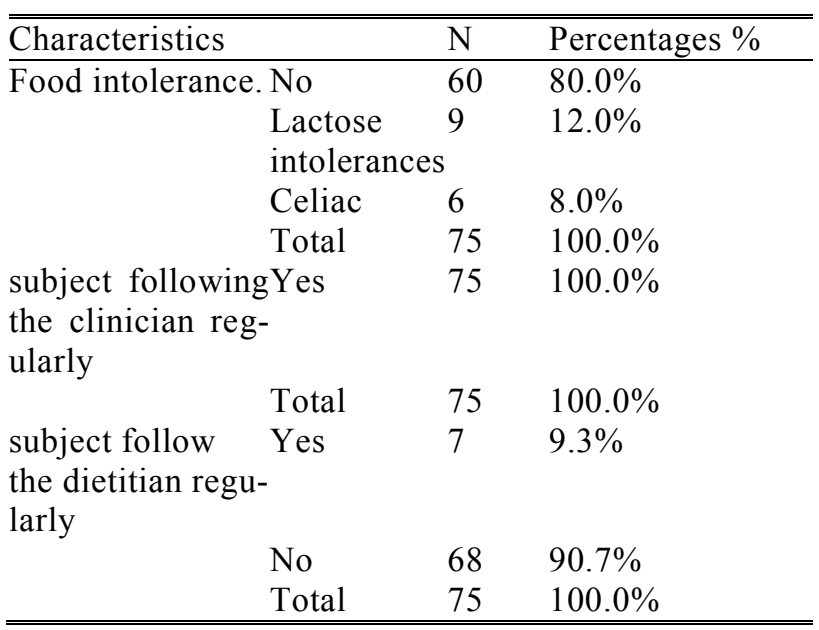

An investigation into types of food consumed by patients: Several questions were directed towards patients about if he or she like or dislike to eat foodstuff and some junk foods. All types of foodstuffs were found significantly consumed $(\mathrm{p}<0.05)$ (Table $7 \mathrm{~A})$. Furthermore, some junk foods that were reported to be highly consumed include sweets, crackers, canned foods, and juices $(p<0.05)$. However, other foods were reported to be less consumed, including eggs, carbonated drinks, fast food, fatty foods, coffee, and tea $(p>0.05)$ (Table 7 B).
Table (7A): Common foodstuffs and junk food consumed by the patients:

\begin{tabular}{|c|c|c|c|c|}
\hline \multicolumn{2}{|l|}{ Food items } & $\mathrm{N}$ & Percentages $\%$ & $\begin{array}{ll}\text { *P } & \text { val } \\
\text { ues } & \\
\end{array}$ \\
\hline \multirow{4}{*}{ Red meat } & & & & \\
\hline & Yes & 62 & $82.1 \%$ & 0.000 \\
\hline & No & 13 & $17.3 \%$ & \\
\hline & Total & 75 & $100.0 \%$ & \\
\hline \multirow[t]{3}{*}{ Poultry } & Yes & 35 & $64.66 \%$ & \\
\hline & No & 40 & $53.33 \%$ & \\
\hline & Total & 75 & $100.0 \%$ & \\
\hline \multirow[t]{3}{*}{ Fish } & Yes & 70 & $94.7 \%$ & 0.000 \\
\hline & No & 5 & $5.3 \%$ & \\
\hline & Total & 75 & $100.0 \%$ & \\
\hline \multirow[t]{3}{*}{ Eggs } & Yes & 45 & $60.0 \%$ & 0.08 \\
\hline & No & 30 & $40.0 \%$ & \\
\hline & Total & 75 & $100.0 \%$ & \\
\hline \multirow[t]{3}{*}{ Rice } & Yes & 67 & $89.4 \%$ & 0.000 \\
\hline & No & 8 & $10.6 \%$ & \\
\hline & Total & 75 & $100.0 \%$ & \\
\hline \multirow[t]{3}{*}{ Couscous } & Yes & 65 & $86.7 \%$ & 0.000 \\
\hline & No & 10 & $13.4 \%$ & \\
\hline & Total & 75 & $100.0 \%$ & \\
\hline \multirow[t]{3}{*}{ Pasta } & Yes & 67 & $89.4 \%$ & 0.000 \\
\hline & No & 8 & $10.6 \%$ & \\
\hline & Total & 75 & $100.0 \%$ & \\
\hline \multirow[t]{3}{*}{ Legumes } & Yes & 50 & $66.7 \%$ & 0.000 \\
\hline & No & 25 & $33.4 \%$ & \\
\hline & Total & 75 & $100.0 \%$ & \\
\hline \multirow[t]{3}{*}{ Fruits } & Yes & 70 & $93.3 \%$ & 0.000 \\
\hline & No & 5 & $6.7 \%$ & \\
\hline & Total & 75 & $100.0 \%$ & \\
\hline \multirow[t]{3}{*}{ Vegetables } & Yes & 70 & $93.3 \%$ & 0.000 \\
\hline & No & 5 & $6.7 \%$ & \\
\hline & Total & 75 & $100.0 \%$ & \\
\hline \multirow[t]{3}{*}{ Other cereals } & Yes & 65 & $86.7 \%$ & 0.000 \\
\hline & No & 10 & $13.3 \%$ & \\
\hline & Total & 75 & $100.0 \%$ & \\
\hline
\end{tabular}


Table (7B): common food stuffs and junk food consumed by the patients:

\begin{tabular}{|c|c|c|c|c|}
\hline \multicolumn{2}{|l|}{$\overline{\text { Food items }}$} & \multirow{2}{*}{$\begin{array}{l}\mathrm{N} \\
45\end{array}$} & \multirow{2}{*}{$\begin{array}{l}\text { Percentages } \\
\% \\
60.0 \%\end{array}$} & \multirow{2}{*}{$\begin{array}{l}* \mathrm{P} \text { values } \\
0.08\end{array}$} \\
\hline Fatty food & Yes & & & \\
\hline & No & 30 & $40.0 \%$ & \\
\hline & Total & 75 & $100.0 \%$ & \\
\hline \multirow[t]{3}{*}{ Sweets } & Yes & 60 & $80.0 \%$ & 0.004 \\
\hline & No & 15 & $20.0 \%$ & \\
\hline & Total & 75 & $100.0 \%$ & \\
\hline \multirow[t]{3}{*}{ Crackers } & Yes & 60 & $80.0 \%$ & 0.004 \\
\hline & No & 15 & $20.0 \%$ & \\
\hline & Total & 75 & $100.0 \%$ & \\
\hline \multirow{3}{*}{$\begin{array}{l}\text { Canned } \\
\text { food }\end{array}$} & Yes & 55 & $73.3 \%$ & 0.01 \\
\hline & No & 20 & $26.7 \%$ & \\
\hline & Total & 75 & $100.0 \%$ & \\
\hline \multirow{3}{*}{$\begin{array}{l}\text { Starchy } \\
\text { food }\end{array}$} & Yes & 57 & $76.0 \%$ & 0.01 \\
\hline & No & 18 & $24.0 \%$ & \\
\hline & Total & 75 & $100.0 \%$ & \\
\hline \multirow[t]{3}{*}{ Juices } & Yes & 57 & $76.0 \%$ & 0.01 \\
\hline & No & 18 & $24.0 \%$ & \\
\hline & Total & 75 & $100.0 \%$ & \\
\hline \multirow{3}{*}{$\begin{array}{l}\text { Carbonatec } \\
\text { drink }\end{array}$} & Yes & 20 & $26.7 \%$ & \\
\hline & No & 55 & $73.3 \%$ & \\
\hline & Total & 75 & $100.0 \%$ & \\
\hline \multirow[t]{3}{*}{ Fast food } & Yes & 40 & $53.3 \%$ & \\
\hline & No & 35 & $46.7 \%$ & \\
\hline & Total & 75 & $100.0 \%$ & \\
\hline \multirow[t]{3}{*}{ Coffee } & Yes & 5 & $6.7 \%$ & \\
\hline & No & 70 & $93.3 \%$ & \\
\hline & Total & 75 & $100.0 \%$ & \\
\hline \multirow[t]{3}{*}{ Tea } & Yes & 6 & $8.0 \%$ & \\
\hline & No & 69 & $92.0 \%$ & \\
\hline & Total & 75 & $100.0 \%$ & \\
\hline
\end{tabular}

$\overline{* \text { Chi-square test was done and at } \alpha<0.05 \text { considered signifi- }}$ cant.

\section{DISCUSSION}

Nephrotic syndrome is a set of signs or symptoms that may point to kidney problems. Nephrotic syndrome is a serious chronic disease in children, characterized by minimal-change disease in the majority of cases (Kopple \& Massry, 2013). In the present study, the total number of patients was 75 , and the age of patients ranged from 1-18 years old. The mean \pm SD of the age was $9 \pm 2$ years old. Nephrotic syndrome reaches a peak at age group 10 years old and declines with age progression between 16-18 years old to reach from 14\% to $2 \%$. The more predominant age group was $6-10$ years $(p=0.04)$. In comparison to females, there was a significant increase in nephrotic syndrome in males by 2.6 times $(p=0.000)$. Pediatric nephrotic syndrome has been shown to occur at an age between 3-6 years old and reach a maximum at age 8 years old (Byham-Gray et al., 2014 ; Lenenno et al., 2010).

In other studies conducted in Canada (Grimbert et al., 2003) the mean age of 8 years, and the peak between 2-5 years were not similar to our results. Regarding the gender characteristics, our study found that male patients were more prone to and suffering from nephrotic syndrome and the ration of male to female was $(2.6: 1)$. In a recent publication (Lenenno et al., 2010), it was reported that $(\mathrm{M}: \mathrm{F}=2.1: 1)$. This male predominance was documented in other publications carried out in the United States of America with the same ratio. On the other hand, another study done in Monitored Canada showed female predominance with (F:M = 1:0.9) (ByhamGray et al., 2014). Overall, our study reflected significantly higher values of males suffering from nephrotic syndrome than earlier mentioned studies.

In nephrotic syndrome patients, the blood biochemical test showed abnormally low levels of laboratory values for total protein, albumin, hemoglobin, HCT, MCV, WBC, (gran \%), calcium, and sodium, and high levels for lymphocyte (mid\%), urea, creatinine, ESR, potassium, hematuria, serum cholesterol, TG, and VLDL. In addition to low levels of protein, albumin, and hemoglobin in the blood and an increased in their filtration by the kidney due to minimal changes of disease by which Nephrotic syndrome is a common 
chronic disorder, characterized by alterations of perm selectivity at the glomerular capillary wall, resulting in its inability to restrict the urinary loss of protein (Kopple \& Massry, 2013).

Low calcium levels in the serum resulted from low parathyroid hormone levels in the blood, which lead to the inability of the kidney to reabsorb calcium and due to a reduction in albumin-bound fraction (Kopple \& Massry, 2013). The erythrocyte sedimentation rate (ESR) is elevated in almost all patients with nephrotic syndrome. A direct relationship between the degree of proteinuria and the ESR was approximately 10 times the daily rate of protein excretion (Latta et al., 2001; Schrier \& Fassett, 1998). The elevation of lipid profile, especially serum TG and cholesterol were well documented in several studies (Kaysen, 1994), but nothing is mentioned for VLDL. This might be indirectly through the relation between serum TG and VLDL. Low protein, sodium, and high potassium were found in patients and this could explain why water was retained in the body because of renal insufficiency (Harris \& Ismail, 1994).

Several studies that showed patients with nephrotic syndrome, exhibited high sodium or sodium retention (Gordillo \& Spitzer, 2009) But this result did not correspond with our findings. In addition, the presence of such findings has been shown to correlate with elevated plasma renin, aldosterone, norepinephrine, and vasopressin levels (Barnett et al., 1981). The common indicator for nephrotic syndrome in children and adolescences was protein in urea and the manifestation of parasites in the urinalysis samples (Niaudet P: Steroid-resistant idiopathic nephrotic syndrome in children. InAvner ED, Harmon WE,). In the present work, there was a significant increase of proteinuria $(p=0.000)$, and an increase of infection manifested by parasites in about $48 \%$ of cases. Increased predisposition to infections occurs due to loss of immunoglobulins, complement, and properdin, altered $\mathrm{T}$ cell functions, immunosuppressive therapy, and the presence of edema (Latta et al., 2001).

In addition, risk factors for infection include low serum IgG levels due to urinary loss of $\mathrm{IgG}$, and abnormal $\mathrm{T}$ lymphocyte function (Eskandarifar et al., 2017; Latta et al., 2001) In the present study, we further investigate the possible risk factors for nephrotic syndrome, which include the ranking of a child in the family, history of the labor situation, birth weight, family history, and consanguinity. The most common child who got nephrotic syndrome was ranking second in the family. We also found that those born with a low birth weight have a high significance for nephrotic syndrome $(p=0.000)$. Neither Family history nor consanguinity play a further role in the development of nephrotic diseases. Regarding the labor situation, around 46.6\% showed delivery by cesarean section. The aforementioned factors were not fully established as causative factors for nephrotic syndrome. About $85.3 \%$ of patients were diagnosed as congenital nephrotic syndrome $(p=0.000)$, and nephrotic syndrome has been associated with some chronic disease including mostly respiratory diseases, HTN and diabetes $26.6 \%, 17.4$ and $9.4 \%$ respectively. The most complications reported by patients were Proteinuria and edema $(p=0.02)$. Proteinuria and edema were shown in several studies to be the major symptoms of nephrotic syndrome (20).

Diagnosis of nephrotic syndrome requires the presence of edema, massive proteinuria $(>40$ $\mathrm{mg} / \mathrm{m} 2 / \mathrm{hr}$ or a urine protein/creatinine ratio $>2.0 \mathrm{mg} / \mathrm{mg})$, and hypoalbuminemia $(<2.5$ $\mathrm{g} / \mathrm{dl})(.3,4)$. The edema in nephrotic syndrome is generally presumed to result from massive proteinuria, which leads to hypoalbuminemia and retention of sodium and water to compensate for intravascular volume depletion. In the current work, the majority of patients were shown to have received cortico- 
steroid medication (92\%). However, other medication was used but less frequently. Those medications include (diuretics, antihypertensive agents, calcineurin inhibitors, and intravenous (IV) albumin. Oral corticosteroids form the cornerstone for the management of most children with nephrotic syndrome (Barnett et al., 1981).

Other medications have been used by nephrotic syndrome patients in several publications (Eskandarifar et al., 2017). Because of increased prevalence of hypertension, retention of potassium, and proteinuria in patients with nephrotic syndrome, therefore one of the strategies is keeping lower blood pressure and decreasing electrolyte retention, and increasing blood total protein through using a salt-restricted diet and a protein high diet (Grimbert et al., 2003). The present findings completely agree with the previous work done by (Avner et al., 2016; Eddy \& Symons, 2003).

The anthropometric measurements carried out for patients were body weight, height for (BMI percentile), and mid-arm circumferences for (degree of protein-energy malnutrition PEM). More than $50 \%$ of patients had an increased BMI to the degree of obesity $(p=0.000)$, but no degree of PEM was identified in patients by MAC. Increased body weight (obesity) could be due to edema, and this is one of the most given explanations (Hulton et al., 1994; Kapur et al., 2009). However, some investigators reported that patients with nephrotic diseases have a low weight (Kaysen et al., 1986; Rath, 1997).

Some food intolerance has been determined among the patients and represents about $20 \%$. This included lactose and gluten intolerance. The reason for such problems is probably due to the remission of immunoglobulin after steroid therapy. Also, it has been found that the neglect of the role dieticians was highly reported by the patients $(91 \%)$. The types of food consumed by patients were also in- volved in the study in order to confirm if the patients follow recommended food guidelines or not. All types of foodstuffs were found to be significantly consumed $(p<0.05)$ (Table 7A). Furthermore, some junk foods that were reported to be highly consumed include sweets, crackers, canned foods, and juices $(p<0.05)$. However, there were other foods which were reported to be less consumed including eggs, carbonated drink, fast food, fatty foods coffee, and tea $(p>0.05)$. This finding agrees with the earlier finding by which the food consumptions were shown to be emptier in calories, which resultant in the high body weight of the patients (Rath, 1997). To sum up, Nephrotic syndrome was shown to significantly affect the age groups 6-10 years and increased in males. The causes of nephrotic syndrome were mainly congenital. There were a number of biochemical abnormalities including low levels of laboratory values for total protein, albumin, hemoglobin, HCT, MCV, WBC, (gran\%), calcium, and sodium, and high levels for lymphocyte (mid \%), urea, creatinine, ESR, potassium, hematuria, serum cholesterol, TG, and VLDL. Proteinuria and edema were the most complications reported by patients.

\section{CONCLUSION}

The present study revealed that nephrotic syndrome significantly increased in males $(\mathrm{p}<0.05)$ and the $\mathrm{M}: \mathrm{F}$ ratio was 2.6:1. Also, it has been shown that the age groups between 6-10 years are more prone to and suffering from nephrotic disease $(\mathrm{p}<0.05)$. Furthermore, a peak of nephrotic syndrome was reported at age 10 years old. In the current work, we found abnormal low blood levels for total protein, albumin, hemoglobin, HCT, MCV, WBC, (gran \%), calcium and sodium, and high levels for lymphocyte (mid \%), urea, creatinine, ESR, potassium, hematuria, serum cholesterol, TG, and VLDL. The most common signs of nephrotic diseases that have been identified in patients were protein in urea and edema (proteinuria) $(\mathrm{p}=0.000)$ with 
causative agent manifestation of parasites in the urinalysis samples. In the present work, the most common child who got nephrotic syndrome ranked second in the family. We also found that those born with a low birth weight have a high significance for nephrotic syndrome $(p=0.000)$, and $85.3 \%$ of patients showed congenital nephrotic syndrome in origin. Furthermore, significantly increased body weight of patients (obesity) $(\mathrm{p}=0.000)$, has been noticed. About $92 \%$ of patients used corticosteroid as a therapeutic agent against nephrotic diseases, and a significant number of patients $(\mathrm{p}<0.05)$, were shown to follow a low salt diet and high protein diet. $20 \%$ of patients reported food intolerance, including milk and gluten. No dietician role has been reported among patients. Therefore, some food patterns were followed through the high consumption of junk foods. Overall, the present data suggested that further work needs to be done for screening high-risk groups, and also optimizing the achievement of normal weight could be a part of reducing complications and underlying diseases.

Our study recommended that patients with nephrotic syndrome should be recognized and managed appropriately to avoid unnecessary complications. Also, all patients should be strongly urged to follow dietitians to minimize weight gain. On the other hand, the result of the present study needs to be further validated in large samples.

\section{REFERENCE}

Avner, E., Harmon, W., Niaudet, P., Yoshikawa, N., Emma, F., \& Goldstein, S. (2016). Pediatric nephrology 7th Ed. Springer Berlin Heidelberg. DOI, 10, 978-973.

Bagga, A., Vasudev, A., Moudgil, A., \& Srivastava, R. (1996). Peripheral blood lymphocyte subsets in idiopathic nephrotic syndrome of childhood. The
Indian Journal of Medical Research, 104, 292-295.

Barnett, H., Edelmann, C., \& Greifer, I. (1981). The primary nephrotic syndrome in children. Identification of patients with minimal change nephrotic syndrome from initial response to prednisone. A report of the international study of kidney disease in children. $J$ Pediatr, 98(4), 561-564.

Byham-Gray, L. D., Burrowes, J. D., \& Chertow, G. M. (2014). Nutrition in kidney disease. Springer Science \& Business Media.

Eddy, A. A., \& Symons, J. M. (2003). Nephrotic syndrome in childhood. The Lancet, 362(9384), 629-639.

Eskandarifar, A., Fotoohi, A., \& yousef Mojtahedi, S. (2017). Nutrition in pediatric nephrotic syndrome. Journal of Pediatric Nephrology, 5(3).

Gordillo, R., \& Spitzer, A. (2009). The nephrotic syndrome. Pediatrics in Review, 30(3), 94.

Grimbert, P., Audard, V., Remy, P., Lang, P., \& Sahali, D. (2003). Recent approaches to the pathogenesis of minimal change nephrotic syndrome. Nephrology Dialysis Transplantation, 18(2), 245-248.

Harris, R. C., \& Ismail, N. (1994). Extrarenal complications of the nephrotic syndrome. American journal of kidney diseases, 23(4), 477-497.

Hulton, S.-A., Neuhaus, T. J., Dillon, M. J., \& Barratt, T. M. (1994). Long-term cyclosporin A treatment of minimalchange nephrotic syndrome of childhood. Pediatric Nephrology, 8(4), 401-403. 
Kapur, G., Valentini, R. P., Imam, A. A., \& Mattoo, T. K. (2009). Treatment of severe edema in children with nephrotic syndrome with diuretics alone-a prospective study. Clinical Journal of the American Society of Nephrology, 4(5), 907-913.

Kaysen, G. A. (1994). Nonrenal complications of the nephrotic syndrome. Annual review of medicine, 45(1), 201-210.

Kaysen, G. A., Gambertoglio, J., Jimenez, I., Jones, H., \& Hutchison, F. N. (1986). Effect of dietary protein intake on albumin homeostasis in nephrotic patients. Kidney international, 29(2), 572-577.

Kopple, J. D., \& Massry, S. G. (2013). Kopple and Massry's nutritional management of renal disease. Lippincott Williams \& Wilkins.

Ladapo, T. A., Esezobor, C. I., \& Lesi, F. E. (2014). Pediatric kidney diseases in an African country: prevalence, spectrum and outcome. Saudi Journal of kidney diseases and transplantation, 25(5), 1110.

Latta, K., von Schnakenburg, C., \& Ehrich, J. H. (2001). A meta-analysis of cytotoxic treatment for frequently relapsing nephrotic syndrome in children. Pediatric Nephrology, 16(3), 271-282.

Lenenno RL.d. Watasonn, and N. J.A. (2010) Weeb "N.ephrotic syndrome in children. Pediatric and child health:20(1)36-42.

Neuhaus, T., Shah, V., Callard, R., \& Barratt, T. (1995). T-lymphocyte activation in steroid-sensitive nephrotic syndrome in childhood. Nephrology Dialysis Transplantation, 10(8), 1348-1352.
Rath, B. (1997). Management of nephrotic syndrome. Indian pediatrics, 34, 10031014.

Schrier, R. W., \& Fassett, R. G. (1998). A critique of the overfill hypothesis of sodium and water retention in the nephrotic syndrome. Kidney international, 53(5), 1111-1117.

Srivastava, R., Mayekar, G., Anand, R., Choudhry, V., Ghai, O., \& Tandon, H. (1975). Nephrotic syndrome in indian children. Archives of disease in childhood, 50(8), 626-630. 


\section{متلازمة أمراض الكلى لدى الأطفال، الخصائص السريرية والحالة التغذوية}

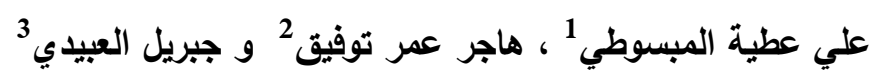

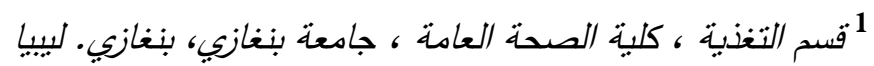
2 مستشفى الأطفال ببنغازي

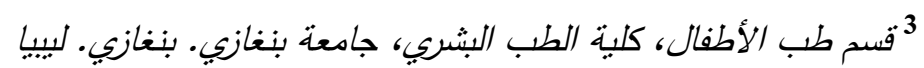

تاريخ الاستلام: 15 فبراير 2020/ تاريخ القبول: 15 يوليو 2020 https://doi.org/10.54172/mjsc.v35i1.226:Doi

المستخلص: المتلازمـة الكلوية (NS)، هي الاضطراب الكلوي المزمن الأكثر شيوعًا للأطفال الذين يعانون من عوامل إختطار

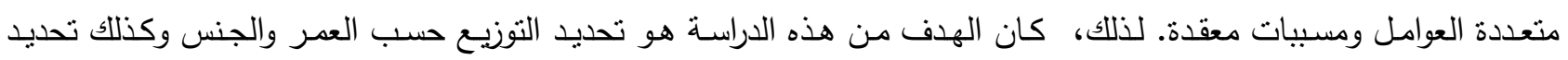

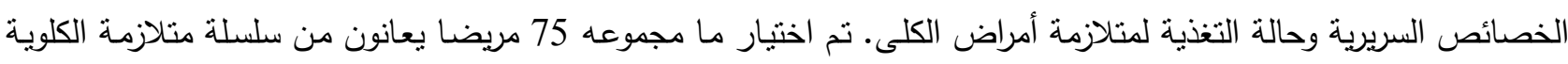

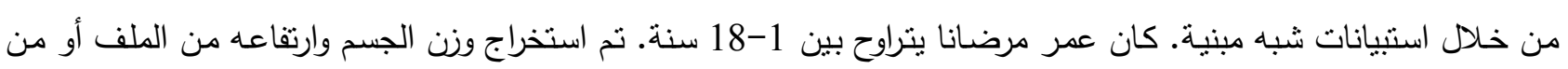

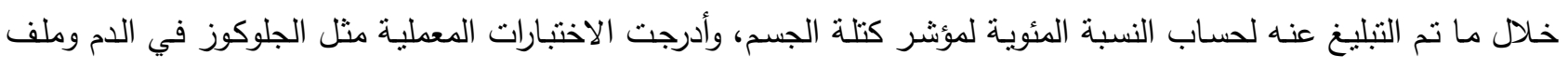
تعريف الدهون وفيتامين H و HbA1C. تم تحليل جميع العينات من خلال متوسط ـ SEM أو Chi-square أتحديد الفروق الهامة. بينت الدراسة الحالية أن 75 مريضا نم تشخيصهم على أنهم متلازمة كلوية. كان متوسط أعمار المرضى 9 سنوات وكانت

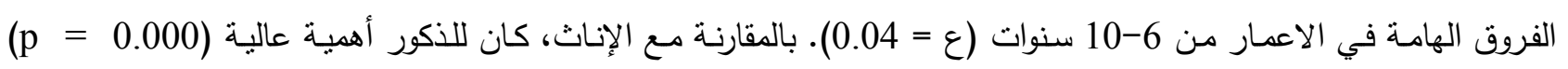
أظهرت الكيمياء الحيوية في الدم مستويات منخفضة من إجمالي البروتين والألبومين والهيموجلوبين و HCT و

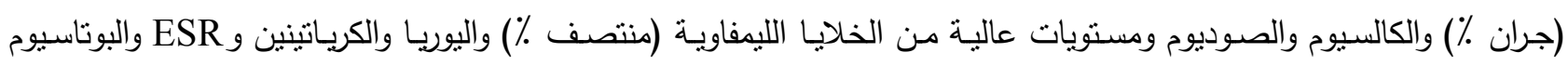
والهيماتوريا وكوليسترول الهصل، VLDL TG. تم تشخيص جميع المرضى على أنهم متلازمة كلى مجهول السبب وأظهرت

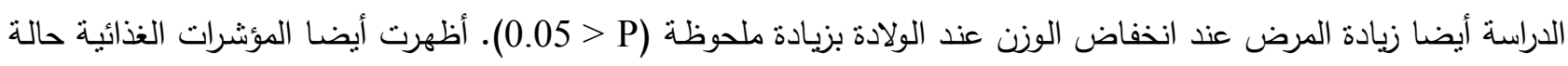

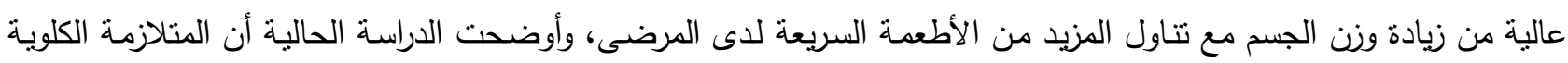

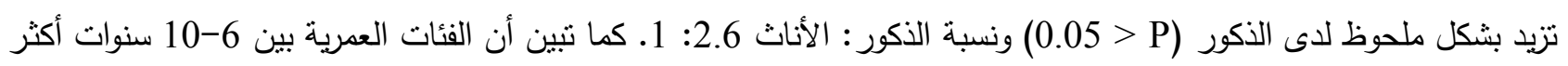

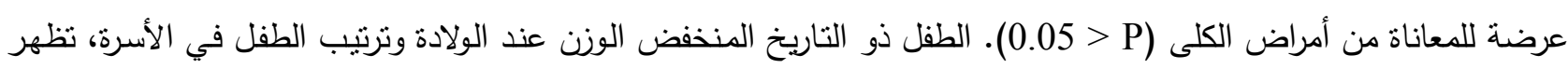
كعامل خطر يساهم في الإصابة بأمراض الكلى (

الكلمات المفتاحية: متلازمة الكلوية؛ حمية؛ طب الأطفال؛ التغذية. 